\title{
Selectivity of Fomesafen to CotTon $^{1}$
}

\author{
Seletividade do Herbicida Fomesafen ao Algodoeiro
}

\author{
OLIVEIRA NETO, A.M. ${ }^{2}$, CONSTANTIN, J. ${ }^{3}$, OLIVEIRA JR. R.S. ${ }^{3}$, BARROSO, A.L.L. ${ }^{4}$, BRAZ, G.B.P. ${ }^{3}$, \\ GUERRA, N. ${ }^{5}$, and GHENO, E.A. ${ }^{3}$
}

\begin{abstract}
The aim of this work was to evaluate the selectivity of fomesafen alone or in a tank mixture with other preemergent herbicides, with or without S-metolachlor application in early postemergence in cotton plant, cultivar DP 555 BG RR ${ }^{\circledR}$. The design utilized was a randomized complete block, organized in a split-plot arrangement, with four replications. For that, 24 herbicides were evaluated with fomesafen $\left(0.45\right.$ and $\left.0.625 \mathrm{~kg} \mathrm{ha}^{-1}\right)$, prometryn (1.25 $\left.\mathrm{kg} \mathrm{ha}^{-1}\right)$, diuron $\left(1.25 \mathrm{~kg} \mathrm{ha}^{-1}\right)$, trifluralin $\left(1.8 \mathrm{~kg} \mathrm{ha}^{-1}\right)$, and S-metolachlor $\left(0.77 \mathrm{~kg} \mathrm{ha}^{-1}\right)$, applied as preemergent, with or without S-metolachlor $\left(0.77 \mathrm{~kg} \mathrm{ha}^{-1}\right)$ applied in early postemergence. The variables evaluated were: phytotoxicity, insertion height of the first reproductive branch, plant height, stand, number of reproductive branches per plant, number of bolls per plant, bolls weight, and productivity of cotton seed. Fomesafen alone or in a tank mixture with preemergent prometryn, diuron, trifluralin and S-metolachlor was selective to cotton plant. Preemergent fomesafen isolated application followed by the application of S-metolachlor in early postemergence was also selective. However, on average, preemergent tank mixtures applied in association with preemergent S-metolachlor early application was not selective to cotton crop.
\end{abstract}

Keywords: chemical control, Protox inhibitor, tank mixture, preemergence.

RESUMO - O objetivo deste trabalho foi avaliar a seletividade da aplicação de fomesafen isolado ou em mistura com outros herbicidas em pré-emergência, associado ou não à aplicação de S-metolachlor em pós-emergência inicial, sobre o algodoeiro, cultivar DP 555 BGRR ${ }^{\circledR}$. O delineamento utilizado foi o de blocos casualizados em esquema de parcelas subdivididas, com quatro repetições. Para isso, avaliaram-se 24 tratamentos herbicidas com fomesafen $\left(0,45\right.$ e 0,625 $\left.\mathrm{kg} \mathrm{ha}^{-1}\right)$, prometryn $\left(1,25 \mathrm{~kg} \mathrm{ha}^{-1}\right)$, diuron $\left(1,25 \mathrm{~kg} \mathrm{ha}^{-1}\right)$, trifluralin $\left(1,8 \mathrm{~kg} \mathrm{ha}^{-1}\right)$ e S-metolachlor $\left(0,77 \mathrm{~kg} \mathrm{ha}^{-1}\right) \mathrm{em}^{-1}$ pré-emergência, associada ou não à aplicação de $S$-metolachlor $\left(0,77 \mathrm{~kg} \mathrm{ha}^{-1}\right)$ em pós-emergência inicial. As variáveis avaliadas foram fitointoxicação, estatura de inserção do primeiro ramo reprodutivo, estatura de plantas, estande, número de ramos reprodutivos por planta, número de capulhos por planta, massa dos capulhos e produtividade do algodão em caroço. A aplicação do fomesafen isolado ou em mistura com prometryn, diuron, trifluralin e S-metolachlor em pré-emergência foi seletiva ao algodoeiro. A aplicação de fomesafen isolado em pré-emergência, seguida da aplicação de S-metolachlor em pós-emergência inicial, também foi seletiva ao algodoeiro. Todavia, em média, a aplicação de misturas em tanque em pré-emergência, complementada com S-metolachlor em pós-emergência inicial, não foi seletiva ao algodoeiro.

Palavras-chave: controle químico, inibidor da Protox, mistura em tanque, pré-emergência.

Recebido para publicação em 30.6.2015 e aprovado em 10.9.2015.

2 CNPq/UFPel/Epagri, Itajaí, Santa Catarina, Brasil, <am.oliveiraneto@gmail.com>; ${ }^{3}$ Universidade Estadual de Maringá, Paraná, Brasil, ${ }^{4}$ Universidade de Rio Verde, Goiás, Brasil; ${ }^{5}$ Universidade Federal de Santa Catarina Centro de Curitibanos, Santa Catarina, Brasil. 


\section{INTRODUCTION}

Chemical weed control with herbicide use is common practice in world agriculture (Beltrão, 2004), and the trend is to increase the use of these compounds, since this technology, which used to be almost exclusively used by large and medium-sized farms, today is also adopted by small farms (Arantes et al., 2014). This is due mainly to chemical control efficiency, its attractive cost and less need for labor, and the fact that it be readily available for use (Guimarães et al., 2007).

The use of preemergent herbicide with residual soil activity has become common practice in cotton crops (Troxler et al., 2002) since in recent years there has been considerable progress in biotypes number of weeds resistant to glyphosate in cotton fields; currently the biggest problem is in the biotypes presenting multiple resistance to EPSPs (5enolpyruvylshikimate 3-phosphate synthase) and ALS (acetolactate synthase enzyme) enzymes inhibitors, which has reduced the traditionally used selective latifolicide mixtures options for postemergence control. Consequently, the use of residual herbicides has become an important tool for weed control in cotton plants (Stephenson IV et al., 2004; Everman et al., 2009). Additionally, preemergence application in cotton plants minimizes early interference of weeds (Raimondi et al., 2014).

The application of early postemergence herbicides in cotton plots, held at the cotyledon stage, is used due to its higher efficiency in weed control already emerged at the time of the application (Arle \& Hamilton, 1976). Another benefit described in the literature is that the application of early postemergence herbicides, especially S-metolachlor, has been more selective than the traditional preemergent application of cotton plants (Culpepper \& York, 1998).

Knowing the importance of chemical control for weed management in cotton crops and the need to incorporate herbicide treatments that are selective and exhibit a good control spectrum, the studies aiming to evaluate the selectivity of herbicide treatments in chemical management systems - involving tank mixtures, doses and application modes - are indispensable today.

In this sense, fomesafen herbicide is an option for management of the weed community infesting cotton plants because it has a mechanism of action still little used commercially (inhibitor of Protox) in the culture and effective for control of important weeds, such as Bidens spp. (beggarticks (among several other names)), Euphorbia heterophylla (common name is milkweed, among many others), and Amaranthus spp. (amaranth) (Bond et al., 2006). This alternative becomes even more important after the identification of Amaranthus palmeri biotypes with multiple resistance to inhibitors of EPSPs (5-enolpyruvylshikimate-3-phosphate synthase) and ALS (acetolactate synthase) in cotton plants crops in the Brazilian state of Mato Grosso (Andrade Jr. et al., 2015).

Experiments conducted in soil and climatic conditions in the United States of America have indicated the possibility of selective use of preemergent fomesafen alone of cotton plants (Main et al., 2012). Therefore, the hypothesis that treatments with fomesafen herbicide could be selective to cotton plants if applied in preemergence was formulated. Therefore, the aim of this study was to evaluate the selectivity of fomesafen application alone or in combination with other preemergent herbicides, coupled or not to the application of early postemergence S-metolachlor in cotton plants, cultivar DP 555 BGRR $^{\circledR}$.

\section{MATERIALS AND METHODS}

The experiment was conducted during the 2012 harvest in the experimental area belonging to Fundação Goiás (Goiás Foundation), located in the Brazilian municipality of Santa Helena de Goiás, GO (1750’19,4" south latitude, 50³5'58,6" west longitude, and $553 \mathrm{~m}$ altitude). The soil of the experimental area was identified as dystrophic red latosol (Embrapa, 2013), presenting $470 \mathrm{~g} \mathrm{~kg}^{-1}$ of clay, $50 \mathrm{~g} \mathrm{~kg}^{-1}$ of silt, $480 \mathrm{~g} \mathrm{~kg}^{-1}$ of sand, with a base saturation of $51 \%$ and $2.89 \%$ of OM (organic matter) and $\mathrm{pH}$ in water of 6.2. Figure 1 shows the climatic conditions observed during the experimental period. The rainfall data were collected daily 


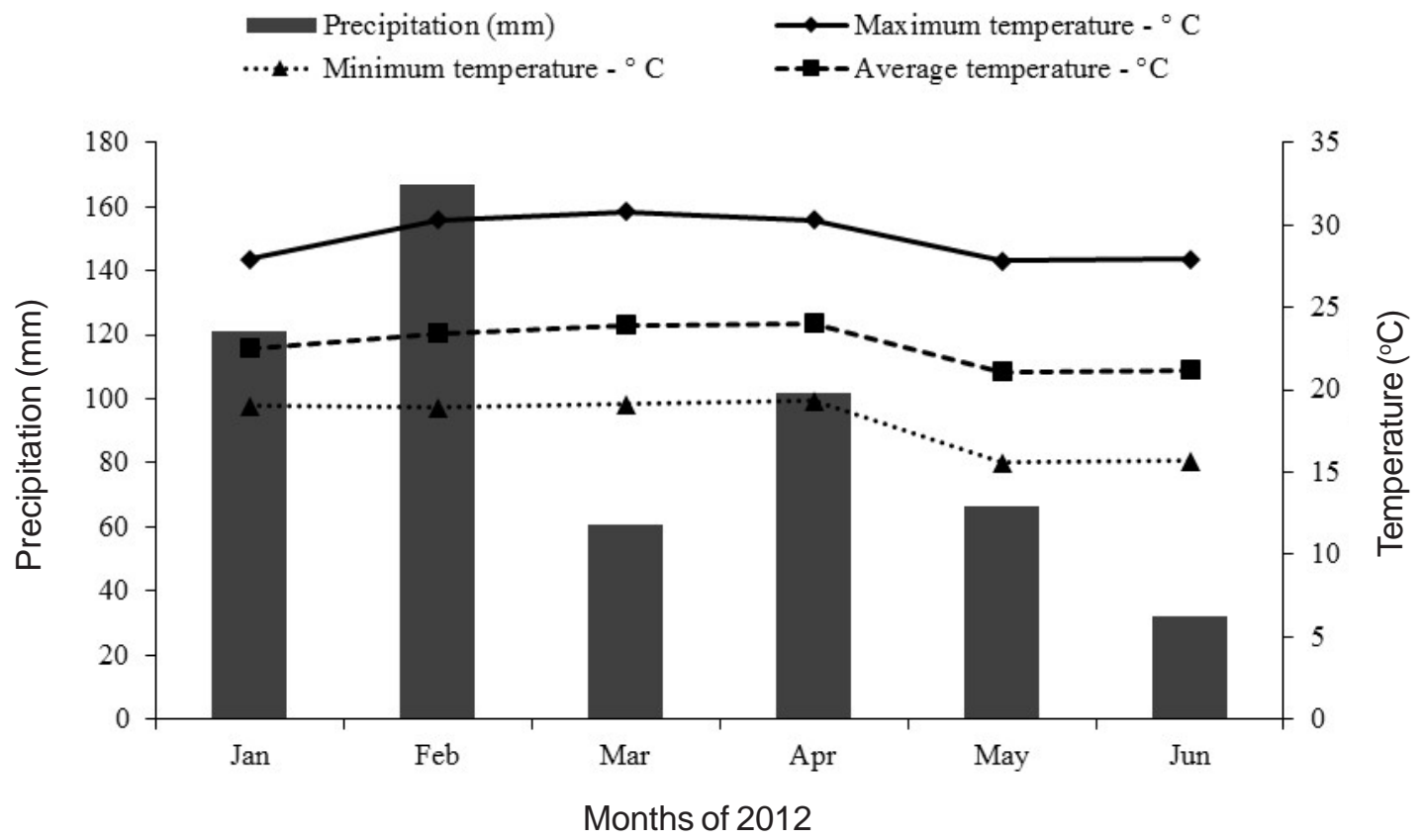

Figure 1 - Rainfall (mm) and the maximum, minimum and average temperatures $\left({ }^{\circ} \mathrm{C}\right)$ observed during the experiment months. Collected rainfall data in the experimental area, and the temperature, collected at the Climatological Station at University of Rio Verde. Santa Helena de Goiás, GO, 2012.

in a rain gauge installed in the experimental area, and temperature readings were obtained at the Climatological Station at University of Rio Verde.

Weed management, prior to cotton sowing, was conducted through two applications of paraquat + Agral (600 g ha $\left.{ }^{-1}+0.5 \% \mathrm{v} \mathrm{v}^{-1}\right)$, at seven and one days before sowing. DP 555 BGRR ${ }^{\circledR}$ cotton cultivar sowing was mechanically done, on February 2, 2012. The seeds were treated with abamectin (Avicta $500 \mathrm{FS}-150 \mathrm{~g}$ a.i. $100 \mathrm{~kg} \mathrm{seed}{ }^{-1}$ ) and thiamethoxam (Cruiser $350 \mathrm{FS}$ $210 \mathrm{~g}$ a.i. $\left.100 \mathrm{~kg} \mathrm{seed}^{-1}\right)$. The spacing adopted among the rows was $0.76 \mathrm{~m}$, and sowing density was of ten seeds per cultivation row meter, at a depth of $3 \mathrm{~cm}$. Simultaneously, basic fertilization was done with $400 \mathrm{~kg} \mathrm{ha}^{-1}$ of formula 02-20-18 (N- $\left.\mathrm{P}_{2} \mathrm{O}_{5}-\mathrm{K}_{2} \mathrm{O}\right)$. Complementary topdressing was used with $100 \mathrm{~kg} \mathrm{ha}^{-1}$ of $\mathrm{N}$ as urea, held 35 days after emergence, mechanized, and with discs fertilizer.

The experiment was conducted in a randomized block design with four replications, and the treatments were distributed in split plots $(24 \times 2)$. The plots were sized in an area of $30.40 \mathrm{~m}^{2}(3.04 \times 10.00 \mathrm{~m})$, and the subplots had a total area of $15.20 \mathrm{~m}^{2}(3.04 \times 5.00 \mathrm{~m})$. The assessed floor area was $6.08 \mathrm{~m}^{2}$ (four meters from the two central rows of each subplot).

The plots consisted of 24 herbicide treatments, applied in early preemergence and postemergence of the cotton plants (Table 1). In the subplots, two situations were evaluated: a subplot that received herbicide application (treated) and another one that did not receive it (untreated). This arrangement allowed the positioning, on the same plot, of plants that were treated with the herbicide, and control plants that did not receive the application thereof. This arrangement is advantageous in selectivity experiments that evaluate a large number of treatments, for it effectively minimizes the variability of the experimental area, contributing to minimizing experimental errors, which leads to accurate results and recommendations on the selectivity of the products evaluated. The effectiveness of this method was confirmed by Fagliari et al. (2001), Dan et al. (2011) and Arantes et al. (2014).

The application of treatments in preemergence was done on February 3, 2012, 
Table 1 - Description of treatments and doses used in the herbicide selectivity experiment for cotton plant crops. Santa Helena de Goiás, GO, 2012

\begin{tabular}{|c|c|}
\hline Treatment (preemergence/sequential) & Dose $\left(\mathrm{kg}\right.$ a.i. $\left.\mathrm{ha}^{-1}\right)$ \\
\hline 1. Fomesafen & 0.45 \\
\hline 2. Fomesafen & 0.625 \\
\hline 3. Fomesafen + prometryn & $0.45+1.25$ \\
\hline 4. Fomesafen + prometryn & $0.625+1.25$ \\
\hline 5. Fomesafen + diuron & $0.45+1.25$ \\
\hline 6. Fomesafen + diuron & $0.625+1.25$ \\
\hline 7. Fomesafen + trifluralin & $0.45+1.8$ \\
\hline 8. Fomesafen + trifluralin & $0.625+1.8$ \\
\hline 9. Fomesafen + S-metolachlor & $0.45+0.77$ \\
\hline 10. Fomesafen + S-metolachlor & $0.625+0.77$ \\
\hline 11. Fomesafen + trifluralin + diuron & $0.45+1.8+1.25$ \\
\hline 12. Fomesafen + trifluralin + prometryn & $0.45+1.8+1.25$ \\
\hline 13. Fomesafen/S-metolachlor & $0.45 / 0.77$ \\
\hline 14. Fomesafen/S-metolachlor & $0.625 / 0.77$ \\
\hline 15. Fomesafen + prometryn/S-metolachlor & $0.45+1.25 / 0.77$ \\
\hline 16. Fomesafen + prometryn/S-metolachlor & $0.625+1.25 / 0.77$ \\
\hline 17. Fomesafen + diuron/S-metolachlor & $0.45+1.25 / 0.77$ \\
\hline 18. Fomesafen + diuron/S-metolachlor & $0.625+1.25 / 0.77$ \\
\hline 19. Fomesafen + trifluralin/S-metolachlor & $0.45+1.8 / 0.77$ \\
\hline 20. Fomesafen + trifluralin/S-metolachlor & $0.625+1.8 / 0.77$ \\
\hline 21. Fomesafen + S-metolachlor/S-metolachlor & $0.45+0.77 / 0.77$ \\
\hline 22. Fomesafen + S-metolachlor/S-metolachlor & $0.625+0.77 / 0.77$ \\
\hline 23. Fomesafen + trifluralin + diuron/S-metolachlor & $0.45+1.8+1.25 / 0.77$ \\
\hline 24. Fomesafen + trifluralin + prometryn/S-metolachlor & $0.45+1.8+1.25 / 0.77$ \\
\hline
\end{tabular}

"+" indicates tank mix and "/" indicates sequential application in early postemergence (cotyledon stage).

the day after sowing. As for the application in early postemergence, it was held on February 11,2012 , three days after emergence (DAE), when the cultivar was in the cotyledon stage. Both applications were done through a precision knapsack sprayer pressurized by $\mathrm{CO}_{2}$, equipped with a $2.50 \mathrm{~m}$ boom, with six AI 110.02 type spray nozzle tips $10.50 \mathrm{~m}$ between tips), pressurized at $206.84 \mathrm{kPa}$, which afforded an application volume equivalent to $200 \mathrm{~L} \mathrm{ha}^{-1}$.

The environmental conditions at the time of application in preemergence were: average temperature of $29.1{ }^{\circ} \mathrm{C}$, average air relative humidity of $52 \%$, wind speed of $3.7 \mathrm{~km} \mathrm{~h}^{-1}$ and moist soil. At the time of early postemergence application, the average temperature was $27.3{ }^{\circ} \mathrm{C}$, with an average relative humidity of $57 \%$, wind speed of $2.4 \mathrm{~km} \mathrm{~h}^{-1}$ and partially moist soil.

Cultivation practices and phytosanitary management (growth regulator, insecticide, fungicide and defoliant) were performed through weekly monitoring, according to crop needs. The culture was maintained continuously free from weed interference by means of four hoeings during the crop cycle (at 5, 20, 40 and $60 \mathrm{DAE}$ ).

Toxicity assessments were done at 4, 16 and 27 days after application (DAA) in early postemergence using a visual scale ranging from 1 to 9 (where 1 represents no symptom and 9 represents death of all plants) (EWRC, 1964). In the preharvest, 160 days after plant emergence (DAE), the final stand of crop was determined by counting all plants of each subplot floor area. At that time, the insertion height of the first sympodial branch, the plant height, the number of sympodial branches per plant and the number of bolls per plant were determined. These measurements were randomly taken in ten plants located in the floor area of each subplot. In the preharvest, boll mass located in the upper and lower parts 
of plants was also evaluated. For this, 15 bolls of each plant were randomly collected within the floor area of each subplot.

At the end of the crop cycle (160 DAE), cotton seed productivity was determined by means of manual harvesting and weighing all open bolls located in the floor area $\left(6.08 \mathrm{~m}^{2}\right)$.

Data were analyzed by comparing the areas treated with herbicides in relation to the untreated area, i.e., there was a partial unfolding of the dual interaction, comparing only the subplots means (treated versus untreated), according to the method described by Fagliari et al. (2001). Data were subjected to analysis of variance by F-test, and when significant, the means were compared by Tukey's test at $10 \%$ probability. The probability level that pointed significance ( $\mathrm{Pr}>\mathrm{F}$ ) between the contrast (treated vs. untreated) was presented, in order to improve the interpretation of results.

In an attempt to seek further answers about the effect of herbicide treatments on cotton seed yield, five additional contrasts were done. The evaluated contrasts are described below:

$\hat{C}_{1}=$ preemergent applications (PRE) vs early postemergence PRE/S-metolachlor (POS) $(\mathrm{T} 1+\mathrm{T} 2+\mathrm{T} 3+\mathrm{T} 4+\mathrm{T} 5+\mathrm{T} 6+\mathrm{T} 7+\mathrm{T} 8+$ $\mathrm{T} 9+\mathrm{T} 10+\mathrm{T} 11+\mathrm{T} 12-\mathrm{T} 13-\mathrm{T} 14-\mathrm{T} 15-$ $\mathrm{T} 16-\mathrm{T} 17-\mathrm{T} 18-\mathrm{T} 19-\mathrm{T} 20-\mathrm{T} 21-\mathrm{T} 22$ $-\mathrm{T} 23-\mathrm{T} 24)$

$\hat{C}_{2}=$ fomesafen alone (FOM) vs mixed fomesafen $(\mathrm{FOM}+)(5 . \mathrm{T} 1+5 . \mathrm{T} 2-\mathrm{T} 3-$ T4 - T5 - T6 - T7 - T8 - T9 - T10 - T11 $-\mathrm{T} 12)$

$\hat{C}_{3}=\mathrm{FOM} / \mathrm{POS} v s \mathrm{FOM}+/ \mathrm{POS}(5 . \mathrm{T} 13+5 . \mathrm{T} 14$

$-\mathrm{T} 15-\mathrm{T} 16-\mathrm{T} 17-\mathrm{T} 18-\mathrm{T} 19-\mathrm{T} 20-$ T21 - T22 - T23 - T24)

$\hat{C}_{4}=\mathrm{FOM} u s \mathrm{FOM} / \mathrm{POS}(\mathrm{T} 1+\mathrm{T} 2-\mathrm{T} 13-\mathrm{T} 14)$

$\hat{C}_{5}=\mathrm{FOM}+v \mathrm{sOM}+/ \mathrm{POS}(\mathrm{T} 3+\mathrm{T} 4+\mathrm{T} 5+$

$\mathrm{T} 6+\mathrm{T} 7+\mathrm{T} 8+\mathrm{T} 9+\mathrm{T} 10+\mathrm{T} 11+\mathrm{T} 12-$ $\mathrm{T} 15-\mathrm{T} 16-\mathrm{T} 17-\mathrm{T} 18-\mathrm{T} 19-\mathrm{T} 20-$ T21 - T22 - T23 - T24)

\section{RESULTS AND DISCUSSION}

During the period between sowing and crop harvest, 430-mm rainfall accumulation was recorded (Figure 1); this value was well below the level required by cotton plants, which comprises between 600 and $800 \mathrm{~mm}$ per cycle. Cotton hydric demand is 2, 4 and $8 \mathrm{~mm} \mathrm{day}^{-1}$ for the emergence phase to the first flower bud, first bud to the first flower, and first flower to the opening boll, respectively (Beltrão et al., 1999). During the cycle, it was observed that the accumulated volume of rain in the phase, which comprises the flowers opening to maturation, was lower than that required by cotton plants (Beltrão et al., 2011).

Precipitation that occurs in the period between sowing and the emergence of cotton seedlings has a significant influence on phytointoxication levels promoted by fomesafen, and high rainfall volumes during this period favor greater phytotoxicity by this herbicide (Main et al., 2012). In the experiment, the highest rainfalls in February occurred after seedling emergence; therefore, the condition was favorable to the lower phytotoxicity of fomesafen.

The observed values of temperature are within appropriate limits for cotton (Oosterhuis, 1999), as, throughout the crop cycle, minimum temperature exceeded $15^{\circ} \mathrm{C}$, maximum temperature did not exceed $31^{\circ} \mathrm{C}$, and the average temperature ranged from 21 to $24{ }^{\circ} \mathrm{C}$ (Figure 1 ).

At the 4 DAA evaluation of S-metolachlor, visual symptoms of phytotoxicity were identified in all herbicide treatments (Table 2). The symptoms observed were wrinkled cotyledon leaf, necrosis as circular spots and some plants were shorter than the control. Main et al. (2012) have described similar phytotoxicity symptoms after application of preemergent fomesafen in cotton plants. These symptoms are related to the way fomesafen operates in plants, since the herbicides inhibiting Protox enzyme cause leaf necrosis as soon as seedlings emerge, and this necrosis results from peroxidation of unsaturated fatty acids of the plasma membrane (Jacobs et al., 1991). 
Table 2 - Phytointoxication at 4 and 16 days after early postemergence herbicide application (DAA) of cotton plants. Santa Helena de Goiás, GO, 2012

\begin{tabular}{|c|c|c|}
\hline \multirow{2}{*}{ Treatment (dose kg a.i. ha ${ }^{-1}$ ) } & \multicolumn{2}{|c|}{ Phytotoxicity } \\
\hline & $4 \mathrm{DAA}$ & $16 \mathrm{DAA}$ \\
\hline 1. Fomesafen -0.45 & 2.0 & 3.0 \\
\hline 2. Fomesafen -0.625 & 2.0 & 3.0 \\
\hline 3. Fomesafen + prometryn $-0.45+1.25$ & 2.0 & 3.3 \\
\hline 4. Fomesafen + prometryn $-0.625+1.25$ & 3.0 & 3.3 \\
\hline 5. Fomesafen + diuron $-0.45+1.25$ & 2.5 & 3.0 \\
\hline 6. Fomesafen + diuron $-0.625+1.25$ & 3.0 & 3.0 \\
\hline 7. Fomesafen + trifluralin $-0.45+1.80$ & 3.0 & 3.0 \\
\hline 8. Fomesafen + trifluralin $-0.625+1.80$ & 2.8 & 3.3 \\
\hline 9. Fomesafen + S-metolachlor $-0.45+0.77$ & 3.0 & 3.3 \\
\hline 10. Fomesafen + S-metolachlor $-0.625+0.77$ & 3.0 & 2.8 \\
\hline 11. Fomesafen + trifluralin + diuron $-0.45+1.80+1.25$ & 2.3 & 3.5 \\
\hline 12. Fom + trifluralin + prometryn $-0.45+1.80+1.25$ & 2.8 & 3.0 \\
\hline 13. Fomesafen/S-metolachlor $-0.45 / 0.77$ & 3.3 & 3.0 \\
\hline 14. Fomesafen/S-metolachlor $-0.625 / 0.77$ & 3.5 & 3.5 \\
\hline 15. Fom + prometryn/S-metolachlor $-0.45+1.25 / 0.77$ & 3.0 & 3.5 \\
\hline 16. Fom + prometryn/S-metolachlor $-0.625+1.25 / 0.77$ & 3.0 & 4.0 \\
\hline 17. Fomesafen + diuron/S-metolachlor $-0.45+1.25 / 0.77$ & 2.8 & 3.3 \\
\hline 18. Fom + diuron/S-metolachlor - $0.625+1.25 / 0.77$ & 3.5 & 3.0 \\
\hline 19. Fom + trifluralin/S-metolachlor - $0.45+1.80 / 0.77$ & 2.3 & 3.3 \\
\hline 20. Fom + trifluralin/S-metolachlor $-0.625+1.80 / 0.77$ & 3.3 & 3.0 \\
\hline 21. Fom + S-metolachlor/S-metolachlor - $0.45+0.77 / 0.77$ & 2.8 & 3.3 \\
\hline 22. Fom + S-metolachlor/S-metolachlor - $0.625+0.77 / 0.77$ & 2.5 & 3.5 \\
\hline 23. Fom + trifluralin + diuron/S-met $-0.45+1.80+1.25 / 0.77$ & 2.5 & 3.5 \\
\hline 24. Fom + trifluralin + prometryn/S-met- $0.45+1.80+1.25 / 0.77$ & 3.5 & 3.0 \\
\hline
\end{tabular}

Fom = fomesafen and S-met = S-metolachlor. “+” indicates tank mix and “/” indicates early postemergence application.

A trend for phytointoxication increasing levels was noted with the application of postemergence S-metolachlor. Phytotoxicity grades ranged from 2 to 3 with the application of herbicides only in preemergence, and 2.3 to 3.5 with joint applications in preemergence and postemergence (Table 2).

At 16 DAA, there was a general increase in phytotoxicity levels in all treatments (Table 2), maintaining the higher phytotoxicity grades with the application of postemergence $\mathrm{S}$-metolachlor. However, there was a predominance of phytointoxication grades around 3 , showing mild symptoms.

At 27 DAA, phytointoxication symptoms were not observed. Main et al. (2012) have found no visual symptoms of phytotoxicity either from 44 DAA of fomesafen application $\left(0.84 \mathrm{~kg} \mathrm{ha}^{-1}\right)$ in experiments conducted in South Carolina (in a sandy soil, $\mathrm{pH}$ of 5.9, 0.8\% of $\mathrm{OM}$ and with precipitation of $111.5 \mathrm{~mm}$ up to 14 DAA) and in Tennessee (in an average textured soil, $\mathrm{pH}$ of $6.0,1.5 \%$ of $\mathrm{OM}$ and precipitation of $93.8 \mathrm{~mm}$ up to $14 \mathrm{DAA}$ ).

There were no significant differences between treatments for the variables insertion height of the first sympodial branch, stand, boll number per plant and mass of bolls on the bottom of the cotton plants. Thus, it was decided not to present the results for these variables. These results are in agreement with what has been described by Main et al. (2012), in which it was found that fomesafen herbicide $\left(0.84 \mathrm{~kg} \mathrm{ha}^{-1}\right)$ has not affected stand and number of bolls of cotton plants.

Applications involving fomesafen have not adversely affected crop growth (height); on the contrary, in some treatments (fomesafen + prometryn $\left(0.45+1.25 \mathrm{~kg} \mathrm{ha}^{-1}\right)$, fomesafen/ S-metolachlor $\left(0.45 / 0.77 \mathrm{~kg} \mathrm{ha}^{-1}\right)$, and 
fomesafen + S-metolachlor/S-metolachlor $\left.\left(0.625+0.77 / 0.77 \mathrm{~kg} \mathrm{ha}^{-1}\right)\right)$ the treated plants were higher than the control (Table 3). Different results were described by Main et al. (2012), where fomesafen significantly affected cotton plants height at doses from $0.49 \mathrm{~g} \mathrm{ha}^{-1}$ (sandy and average textured soils, $\mathrm{pH}$ ranging from 5.3 to 6.4 and $\mathrm{OM}$ between 0.7 and $1.5 \%$ ). The divergent results can be explained by the physical and chemical differences between soils, especially by the textural class and the organic matter content, which are factors that influence fomesafen selectivity to cotton (Karpinski et al., 2014).

Regarding the number of sympodial branches, it was observed that each plant showed between 5.7 and 7.6 reproductive branches (Table 4). The fomesafen + trifluralin + diuron tank mixture, applied in preemergence, was the only treatment that significantly reduced this variable. These results corroborate those found by Main et al. (2012), for whom the single application of fomesafen $\left(0.84 \mathrm{~kg} \mathrm{ha}^{-1}\right)$ has not reduced the number of sympodial branches in the cotton plant.

A negative effect of tank mixtures of fomesafen + diuron $\left(0.45+1.25 \mathrm{~kg} \mathrm{ha}^{-1}\right)$, fomesafen + trifluralin $\left(0.45+1.80 \mathrm{~kg} \mathrm{ha}^{-1}\right)$ and fomesafen + S-metolachlor $(0.625+$ $0.77 \mathrm{~kg} \mathrm{ha}^{-1}$ ) was found, without the application of early postemergence S-metolachlor on the mass accumulation of bolls located on top of the cotton plant (Table 5). In addition, the application of the preemergent fomesafen + prometryn $\left(0.45+1.25 \mathrm{~kg} \mathrm{ha}^{-1}\right)$ mixture, complemented with the application of early postemergence S-metolachlor, has also

Table 3 - Average plant height (cm) in cotton preharvest (160 DAE). Santa Helena de Goiás, GO, 2012

\begin{tabular}{|c|c|c|}
\hline \multirow{2}{*}{ Treatment (dose kg a.i. ha ${ }^{-1}$ ) } & \multicolumn{2}{|c|}{ Size $(\mathrm{cm})$} \\
\hline & Treated & Untreated \\
\hline 1. Fomesafen -0.45 & 70.9 a & $73.9 \mathrm{a}$ \\
\hline 2. Fomesafen -0.625 & $79.3 \mathrm{a}$ & $77.3 \mathrm{a}$ \\
\hline 3. Fomesafen + prometryn $-0.45+1.25$ & $79.5 \mathrm{a}$ & $71.7 \mathrm{~b}$ \\
\hline 4. Fomesafen + prometryn $-0.625+1.25$ & $78.3 \mathrm{a}$ & $79.4 \mathrm{a}$ \\
\hline 5. Fomesafen + diuron $-0.45+1.25$ & $72.6 \mathrm{a}$ & $78.2 \mathrm{a}$ \\
\hline 6. Fomesafen + diuron $-0.625+1.25$ & $74.1 \mathrm{a}$ & $71.7 \mathrm{a}$ \\
\hline 7. Fomesafen + trifluralin $-0.45+1.80$ & $74.6 \mathrm{a}$ & $76.5 \mathrm{a}$ \\
\hline 8. Fomesafen + trifluralin $-0.625+1.80$ & $79.4 \mathrm{a}$ & $79.5 \mathrm{a}$ \\
\hline 9. Fomesafen + S-metolachlor $-0.45+0.77$ & $81.9 \mathrm{a}$ & $78.2 \mathrm{a}$ \\
\hline 10. Fomesafen + S-metolachlor $-0.625+0.77$ & $78.7 \mathrm{a}$ & $78.3 \mathrm{a}$ \\
\hline 11. Fomesafen + trifluralin + diuron $-0.45+1.80+1.25$ & $77.4 \mathrm{a}$ & $75.2 \mathrm{a}$ \\
\hline 12. Fom + trifluralin + prometryn $-0.45+1.80+1.25$ & $76.8 \mathrm{a}$ & $74.9 \mathrm{a}$ \\
\hline 13. Fomesafen/S-metolachlor $-0.45 / 0.77$ & $83.2 \mathrm{a}$ & $76.5 \mathrm{~b}$ \\
\hline 14. Fomesafen/S-metolachlor $-0.625 / 0.77$ & $80.8 \mathrm{a}$ & $75.8 \mathrm{a}$ \\
\hline 15. Fom + prometryn/S-metolachlor $-0.45+1.25 / 0.77$ & $74.3 \mathrm{a}$ & $71.8 \mathrm{a}$ \\
\hline 16. Fom + prometryn/S-metolachlor $-0.625+1.25 / 0.77$ & $78.1 \mathrm{a}$ & $73.9 \mathrm{a}$ \\
\hline 17. Fomesafen + diuron/S-metolachlor $-0.45+1.25 / 0.77$ & $79.0 \mathrm{a}$ & $73.7 \mathrm{a}$ \\
\hline 18. Fom + diuron/S-metolachlor $-0.625+1.25 / 0.77$ & $78.2 \mathrm{a}$ & $73.2 \mathrm{a}$ \\
\hline 19. Fom + trifluralin/S-metolachlor $-0.45+1.80 / 0.77$ & $75.8 \mathrm{a}$ & $71.1 \mathrm{a}$ \\
\hline 20. Fom + trifluralin/S-metolachlor $-0.625+1.80 / 0.77$ & $75.4 \mathrm{a}$ & $71.8 \mathrm{a}$ \\
\hline 21. Fom + S-metolachlor/S-metolachlor - $0.45+0.77 / 0.77$ & $77.0 \mathrm{a}$ & $73.9 \mathrm{a}$ \\
\hline 22. Fom + S-metolachlor/S-metolachlor - $0.625+0.77 / 0.77$ & $79.2 \mathrm{a}$ & $67.6 \mathrm{~b}$ \\
\hline 23. Fom + trifluralin + diuron/S-met $-0.45+1.80+1.25 / 0.77$ & $75.9 \mathrm{a}$ & $73.4 \mathrm{a}$ \\
\hline 24. Fom + trifluralin + prometryn/S-met- $0.45+1.80+1.25 / 0.77$ & $76.1 \mathrm{a}$ & $73.6 \mathrm{a}$ \\
\hline CV $(\%)$ & & \\
\hline LSD (least significant difference) & & \\
\hline
\end{tabular}

Fom = fomesafen and S-met = S-metolachlor. “+” indicates tank mix and “” indicates early postemergence application. Means followed by the same lowercase letter on the row do not differ by Tukey's test at $10 \%$ probability. 
Table 4 - Total number of sympodial branches per plant in cotton preharvest (160 DAE), Santa Helena de Goiás, GO, 2012

\begin{tabular}{|c|c|c|}
\hline \multirow{2}{*}{ Treatment (dose kg a.i. ha ${ }^{-1}$ ) } & \multicolumn{2}{|c|}{ Number of branches } \\
\hline & Treated & Untreated \\
\hline 1. Fomesafen -0.45 & $6.6 \mathrm{a}$ & $6.8 \mathrm{a}$ \\
\hline 2. Fomesafen -0.625 & $6.9 \mathrm{a}$ & $7.1 \mathrm{a}$ \\
\hline 3. Fomesafen + prometryn $-0.45+1.25$ & $6.7 \mathrm{a}$ & $6.7 \mathrm{a}$ \\
\hline 4. Fomesafen + prometryn $-0.625+1.25$ & $6.3 \mathrm{a}$ & $6.5 \mathrm{a}$ \\
\hline 5. Fomesafen + diuron $-0.45+1.25$ & $6.1 \mathrm{a}$ & $6.5 \mathrm{a}$ \\
\hline 6. Fomesafen + diuron $-0.625+1.25$ & $6.9 \mathrm{a}$ & $6.6 \mathrm{a}$ \\
\hline 7. Fomesafen + trifluralin $-0.45+1.80$ & $7.2 \mathrm{a}$ & $6.6 \mathrm{a}$ \\
\hline 8. Fomesafen + trifluralin $-0.625+1.80$ & $7.1 \mathrm{a}$ & $6.4 \mathrm{~b}$ \\
\hline 9. Fomesafen + S-metolachlor $-0.45+0.77$ & $7.5 \mathrm{a}$ & $6.4 \mathrm{~b}$ \\
\hline 10. Fomesafen + S-metolachlor $-0.625+0.77$ & $6.3 \mathrm{a}$ & $6.5 \mathrm{a}$ \\
\hline 11. Fomesafen + trifluralin + diuron $-0.45+1.80+1.25$ & $5.7 \mathrm{~b}$ & $6.5 \mathrm{a}$ \\
\hline 12. Fom + trifluralin + prometryn $-0.45+1.80+1.25$ & $6.7 \mathrm{a}$ & $6.3 \mathrm{a}$ \\
\hline 13. Fomesafen/S-metolachlor $-0.45 / 0.77$ & $6.1 \mathrm{a}$ & $6.6 \mathrm{a}$ \\
\hline 14. Fomesafen/S-metolachlor $-0.625 / 0.77$ & $6.1 \mathrm{a}$ & $6.3 \mathrm{a}$ \\
\hline 15. Fom + prometryn/S-metolachlor $-0.45+1.25 / 0.77$ & $6.4 \mathrm{a}$ & $6.6 \mathrm{a}$ \\
\hline 16. Fom + prometryn/S-metolachlor $-0.625+1.25 / 0.77$ & $6.9 \mathrm{a}$ & $7.0 \mathrm{a}$ \\
\hline 17. Fomesafen + diuron/S-metolachlor $-0.45+1.25 / 0.77$ & $7.6 \mathrm{a}$ & $7.3 \mathrm{a}$ \\
\hline 18. Fom + diuron/S-metolachlor $-0.625+1.25 / 0.77$ & $6.9 \mathrm{a}$ & $7.0 \mathrm{a}$ \\
\hline 19. Fom + trifluralin/S-metolachlor $-0.45+1.80 / 0.77$ & $6.7 \mathrm{a}$ & $6.5 \mathrm{a}$ \\
\hline 20. Fom + trifluralin/S-metolachlor $-0.625+1.80 / 0.77$ & $7.2 \mathrm{a}$ & $6.8 \mathrm{a}$ \\
\hline 21. Fom + S-metolachlor/S-metolachlor $-0.45+0.77 / 0.77$ & $7.2 \mathrm{a}$ & $7.3 \mathrm{a}$ \\
\hline 22. Fom + S-metolachlor/S-metolachlor $-0.625+0.77 / 0.77$ & $6.8 \mathrm{a}$ & $6.3 \mathrm{a}$ \\
\hline 23. Fom + trifluralin + diuron/S-met $-0.45+1.80+1.25 / 0.77$ & $6.2 \mathrm{a}$ & $6.4 \mathrm{a}$ \\
\hline 24. Fom + trifluralin + prometryn/S-met- $0.45+1.80+1.25 / 0.77$ & $6.6 \mathrm{a}$ & $6.4 \mathrm{a}$ \\
\hline CV $(\%)$ & \multicolumn{2}{|c|}{9.52} \\
\hline LSD (least significant difference) & \multicolumn{2}{|c|}{0.75} \\
\hline
\end{tabular}

Fom = fomesafen and S-met = S-metolachlor. “+” indicates tank mix and “/” indicates early postemergence application. Means followed by the same lowercase letter on the row do not differ by Tukey's test at $10 \%$ probability.

impaired this variable. The application of herbicides was more harmful to the mass accumulation in bolls located on top of the cotton plant. For cotton late harvest conditions, this finding is of great importance, as these bolls more effectively contribute with productivity.

There were no significant differences in cotton seed yield where a single application of preemergent herbicides was carried out, regardless of the mixtures evaluated (Table 6). Main et al. (2012) have reported that fomesafen can be safely used in preemergent applications in cotton plants, not damaging productivity and fiber quality (cultivars DP 555 BGRR $^{\circledR}$, DP 117 B2RF ${ }^{\circledR}, 4554$ B2RF $^{\circledR}$ and ST $\left.4357 \mathrm{~B} 2 \mathrm{RF}^{\circledR}\right)$, in doses registered in the United States of America (280 to $420 \mathrm{~g} \mathrm{ha}^{-1}$ ).

However, this trend was not followed when the application of some associations in preemergence was held together with the application of early postemergence S-metolachlor (Table 6). In this condition, the mixtures of fomesafen + diuron $(0.625+$ $\left.1.25 \mathrm{~kg} \mathrm{ha}^{-1}\right)$, fomesafen + trifluralin $(0.625+$ $\left.1.80 \mathrm{~kg} \mathrm{ha}^{-1}\right)$, fomesafen + S-metolachlor $\left(0.625+0.77 \mathrm{~kg} \mathrm{ha}^{-1}\right)$ and fomesafen + trifluralin + diuron $\left(0.45+1.80+1.25 \mathrm{~kg} \mathrm{ha}^{-1}\right)$, combined with the application of S-metolachlor $\left(0.77 \mathrm{~kg} \mathrm{ha}^{-1}\right)$ in the cotyledon stage, significantly reduced cotton seed productivity.

It is observed that the treatments that significantly reduced productivity contained fomesafen at the highest dose in double or triple mixtures among herbicides, indicating that fomesafen dose, quantities of herbicide in the mixture and early postemergence application were decisive for treatments selectivity. One hypothesis for this effect is that Protox inhibiting herbicides such as 
Table 5 - Average boll weight (g) located on top of the cotton plant. Santa Helena de Goiás, GO, 2012

\begin{tabular}{|c|c|c|}
\hline \multirow{2}{*}{ Treatment (dose kg a.i. ha ${ }^{-1}$ ) } & \multicolumn{2}{|c|}{ Higher boll (g) } \\
\hline & Treated & Untreated \\
\hline 1. Fomesafen -0.45 & $3.66 \mathrm{a}$ & $4.08 \mathrm{a}$ \\
\hline 2. Fomesafen -0.625 & $4.49 \mathrm{a}$ & $4.37 \mathrm{a}$ \\
\hline 3. Fomesafen + prometryn $-0.45+1.25$ & $3.58 \mathrm{a}$ & $4.04 \mathrm{a}$ \\
\hline 4. Fomesafen + prometryn $-0.625+1.25$ & $4.41 \mathrm{a}$ & $4.00 \mathrm{a}$ \\
\hline 5. Fomesafen + diuron $-0.45+1.25$ & $3.75 \mathrm{~b}$ & $4.29 \mathrm{a}$ \\
\hline 6. Fomesafen + diuron $-0.625+1.25$ & $3.91 \mathrm{a}$ & $3.99 \mathrm{a}$ \\
\hline 7. Fomesafen + trifluralin $-0.45+1.80$ & $3.93 \mathrm{~b}$ & $4.42 \mathrm{a}$ \\
\hline 8. Fomesafen + trifluralin $-0.625+1.80$ & $4.25 \mathrm{a}$ & $4.33 \mathrm{a}$ \\
\hline 9. Fomesafen + S-metolachlor $-0.45+0.77$ & $4.24 \mathrm{a}$ & $4.29 \mathrm{a}$ \\
\hline 10. Fomesafen + S-metolachlor $-0.625+0.77$ & $3.66 \mathrm{~b}$ & $4.42 \mathrm{a}$ \\
\hline 11. Fomesafen + trifluralin + diuron $-0.45+1.80+1.25$ & $4.58 \mathrm{a}$ & $4.42 \mathrm{a}$ \\
\hline 12. Fom + trifluralin + prometryn $-0.45+1.80+1.25$ & $4.25 \mathrm{a}$ & $4.58 \mathrm{a}$ \\
\hline 13. Fomesafen/S-metolachlor $-0.45 / 0.77$ & $4.16 \mathrm{a}$ & $4.20 \mathrm{a}$ \\
\hline 14. Fomesafen/S-metolachlor $-0.625 / 0.77$ & $4.08 \mathrm{a}$ & $4.16 \mathrm{a}$ \\
\hline 15. Fom + prometryn/S-metolachlor $-0.45+1.25 / 0.77$ & $3.75 \mathrm{~b}$ & $4.29 \mathrm{a}$ \\
\hline 16. Fom + prometryn/S-metolachlor $-0.625+1.25 / 0.77$ & $3.92 \mathrm{a}$ & $4.25 \mathrm{a}$ \\
\hline 17. Fomesafen + diuron/S-metolachlor $-0.45+1.25 / 0.77$ & $3.71 \mathrm{~b}$ & $4.62 \mathrm{a}$ \\
\hline 18. Fom + diuron/S-metolachlor $-0.625+1.25 / 0.77$ & $4.16 \mathrm{a}$ & $4.25 \mathrm{a}$ \\
\hline 19. Fom + trifluralin/S-metolachlor $-0.45+1.80 / 0.77$ & $3.86 \mathrm{~b}$ & $4.45 \mathrm{a}$ \\
\hline 20. Fom + trifluralin/S-metolachlor $-0.625+1.80 / 0.77$ & $4.25 \mathrm{a}$ & $4.50 \mathrm{a}$ \\
\hline 21. Fom + S-metolachlor/S-metolachlor - $0.45+0.77 / 0.77$ & $4.16 \mathrm{a}$ & $4.58 \mathrm{a}$ \\
\hline 22. Fom + S-metolachlor/S-metolachlor - $0.625+0.77 / 0.77$ & $3.75 \mathrm{~b}$ & $4.25 \mathrm{a}$ \\
\hline 23. Fom + trifluralin + diuron/s-met $-0.45+1.80+1.25 / 0.77$ & $3.99 \mathrm{a}$ & $4.08 \mathrm{a}$ \\
\hline 24. Fom + trifluralin + prometryn/s-met- $0.45+1.80+1.25 / 0.77$ & $3.92 \mathrm{a}$ & $4.29 \mathrm{a}$ \\
\hline CV $(\%)$ & \multicolumn{2}{|c|}{9.79} \\
\hline LSD (least significant difference) & \multicolumn{2}{|c|}{0.48} \\
\hline
\end{tabular}

Fom = fomesafen and S-met = S-metolachlor. “+” indicates tank mix and “/” indicates early postemergence application. Means followed by the same lowercase letter on the row do not differ by Tukey's test at $10 \%$ probability.

fomesafen are typically selective because of reduced mobility in the plant and higher rate of metabolism (Fausey et al., 2000); thus, increasing the dose may have increased fomesafen concentration to a quantity exceeding the cotton plant metabolizer capacity.

Silva et al. (2013) have found no differences between cotton seed productivity (cultivars FM 966 and DP 604) of plants treated only with preemergent fomesafen + prometryn $\left(0.375+1.0 \mathrm{~kg} \mathrm{ha}^{-1}\right)$ and those which received additional application of early postemergence S-metolachlor $\left(0,96 \mathrm{~kg} \mathrm{ha}^{-1}\right)$; however, this experiment was not conducted free from weed interference.

In a series of experiments in sandy soil (130 g kg-1 of clay, $\mathrm{pH}$ of 6.3 and $1.1 \%$ of $\mathrm{OM}$ ) in western Bahia, it was concluded that the application of early postemergence
S-metolachlor is selective and safe when performed after the application of a double mixture of preemergent herbicides, and this mixture should involve a herbicide with an action predominantly on grasses (clomazone or trifluralin) and another one with an action on broad-leaved species (diuron or prometryn) (Arantes, 2012).

Also in relation to productivity, two points deserve consideration. First, in general, most of the herbicide treatments had a mean cotton seed yield numerically less than the respective control. Second, productivity in treatments that received only preemergence application was, on average, $118 \mathrm{~kg} \mathrm{ha}^{-1}$, which is higher than in treatments with early preemergence and postemergence applications. Thus, analysis of contrasts was held in order to draw broader conclusions about these effects. 
Table 6 - Cotton seed yield (kg ha $\left.{ }^{-1}\right)$. Santa Helena de Goiás, GO, 2012

\begin{tabular}{|c|c|c|c|}
\hline \multirow{2}{*}{ Treatment (dose kg a.i. ha ${ }^{-1}$ ) } & \multicolumn{2}{|c|}{ Yield (kg ha $\left.{ }^{-1}\right)$} & \multirow{2}{*}{$\operatorname{Pr}>\mathrm{F}$} \\
\hline & Treated & Untreated & \\
\hline 1. Fomesafen -0.45 & $1574.8 \mathrm{a}$ & $1723.9 \mathrm{a}$ & 0.35 \\
\hline 2. Fomesafen -0.625 & $1768.1 \mathrm{a}$ & $1934.6 \mathrm{a}$ & 0.29 \\
\hline 3. Fomesafen + prometryn $-0.45+1.25$ & $1605.7 \mathrm{a}$ & $1751.6 \mathrm{a}$ & 0.36 \\
\hline 4. Fomesafen + prometryn $-0.625+1.25$ & $1854.4 \mathrm{a}$ & $1923.3 \mathrm{a}$ & 0.66 \\
\hline 5. Fomesafen + diuron $-0.45+1.25$ & $1988.1 \mathrm{a}$ & 2032.3 a & 0.78 \\
\hline 6. Fomesafen + diuron $-0.625+1.25$ & $1903.8 \mathrm{a}$ & 2052.8 a & 0.35 \\
\hline 7. Fomesafen + trifluralin $-0.45+1.80$ & $2076.5 \mathrm{a}$ & 2026.1 a & 0.75 \\
\hline 8. Fomesafen + trifluralin $-0.625+1.80$ & $1955.2 \mathrm{a}$ & 2150.5 a & 0.22 \\
\hline 9. Fomesafen + S-metolachlor $-0.45+0.77$ & $1809.2 \mathrm{a}$ & $2067.2 \mathrm{a}$ & 0.11 \\
\hline 10. Fomesafen + S-metolachlor $-0.625+0.77$ & $1790.7 \mathrm{a}$ & 1899.7 a & 0.49 \\
\hline 11. Fomesafen + trifluralin + diuron $-0.45+1.80+1.25$ & $2143.3 \mathrm{a}$ & 2290.3 a & 0.35 \\
\hline 12. Fom + trifluralin + prometryn $-0.45+1.80+1.25$ & $2098.1 \mathrm{a}$ & $2212.2 \mathrm{a}$ & 0.47 \\
\hline 13. Fomesafen/S-metolachlor $-0.45 / 0.77$ & $1821.5 \mathrm{a}$ & 2013.8 a & 0.22 \\
\hline 14. Fomesafen/S-metolachlor $-0.625 / 0.77$ & $1786.6 \mathrm{a}$ & $1791.7 \mathrm{a}$ & 0.97 \\
\hline 15. Fom + prometryn/S-metolachlor $-0.45+1.25 / 0.77$ & $1827.7 \mathrm{a}$ & 1833.7 a & 0.97 \\
\hline 16. Fom + prometryn/S-metolachlor $-0.625+1.25 / 0.77$ & $1872.9 \mathrm{a}$ & 2009.7 a & 0.39 \\
\hline 17. Fomesafen + diuron/S-metolachlor $-0.45+1.25 / 0.77$ & $1998.4 \mathrm{a}$ & $2182.4 \mathrm{a}$ & 0.24 \\
\hline 18. Fom + diuron/S-metolachlor $-0.625+1.25 / 0.77$ & $1671.5 \mathrm{~b}$ & $1966.5 \mathrm{a}$ & 0.06 \\
\hline 19. Fom + trifluralin/S-metolachlor $-0.45+1.80 / 0.77$ & $1946.9 \mathrm{a}$ & 2098.1 a & 0.34 \\
\hline 20. Fom + trifluralin/S-metolachlor $-0.625+1.80 / 0.77$ & $1766.0 \mathrm{~b}$ & 2053.9 a & 0.07 \\
\hline 21. Fom + S-metolachlor/S-metolachlor $-0.45+0.77 / 0.77$ & $1920.2 \mathrm{a}$ & 2014.8 a & 0.54 \\
\hline 22. Fom + S-metolachlor/S-metolachlor $-0.625+0.77 / 0.77$ & $1457.7 \mathrm{~b}$ & $1932.6 \mathrm{a}$ & 0.00 \\
\hline 23. Fom + trifluralin + diuron/s-met $-0.45+1.80+1.25 / 0.77$ & $1539.9 \mathrm{~b}$ & $1889.4 \mathrm{a}$ & 0.03 \\
\hline 24. Fom + trifluralin + prometryn/s-met $-0.45+1.80+1.25 / 0.77$ & $1548.1 \mathrm{a}$ & $1710.5 \mathrm{a}$ & 0.31 \\
\hline CV $(\%)$ & \multicolumn{3}{|c|}{11.66} \\
\hline LSD (least significant difference) & \multicolumn{3}{|c|}{261.26} \\
\hline
\end{tabular}

fom = fomesafen, S-met = S-metolachlor, diu = diuron, pro = prometryn and tri = trifluralin. “+” indicates tank mix and “/” indicates early postemergence application. Means followed by the same lowercase letter on the row do not differ by Tukey’s test at $10 \%$ probability.

Although treatments that received only preemergent application have shown higher productivity compared to treatments with an additional application of postemergence S-metolachlor $\left(\hat{C}_{1}\right)$, this effect was not significant ( $p>0.10)$ (Table 7$)$. The prometryn, diuron, trifluralin and S-metolachlor mixture with fomesafen, regardless of the dose, has not influenced the cotton seed productivity $\left(\hat{C}_{2}\right.$ and $\hat{C}_{3}$ ). Early postemergence S-metolachlor application after the application of fomesafen alone has not damaged cotton plant yield $\left(\hat{C}_{4}\right)$. However, when performing the application of a tank mix involving preemergent fomesafen followed by early postemergence S-metolachlor application, there was a negative effect on cotton seeds yield $\left(\hat{C}_{5}\right)$. Thus, when choosing to apply mixtures involving preemergent fomesafen, it is not feasible to apply early postemergence S-metolachlor.

It has already been proven in previous research that phytotoxicity caused by

Table 7 - Estimation of contrasts and significance level for contrast to be significant to the variable cotton seed productivity. Santa Helena de Goiás, GO, 2012

\begin{tabular}{|l|c|c|}
\hline \multicolumn{1}{|c|}{ Contrast } & Estimate & $\operatorname{Pr}>$ Fc \\
\hline$\hat{C}_{1}=$ PRE $v s$ PRE/POS & $139.29^{\mathrm{ns}}$ & 0.13 \\
\hline$\hat{C}_{2}=$ FOM $v s$ FOM + & $-277.14^{\mathrm{ns}}$ & 0.12 \\
\hline$\hat{C}_{3}=$ FOM/POS $v s$ FOM +/POS & $49.14^{\mathrm{ns}}$ & 0.78 \\
\hline$\hat{C}_{4}=\mathrm{FOM} v s$ FOM/POS & $-132.61^{\mathrm{ns}}$ & 0.56 \\
\hline$\hat{C}_{5}=\mathrm{FOM}+v s$ FOM $+/ \mathrm{POS}$ & $193.67^{*}$ & 0.06 \\
\hline
\end{tabular}

${ }^{n s}$ nonsignificant at $10 \%$ and $*$ significant at $10 \%$ probability. 
S-metolachlor in broad-leaved species is the reduction in root growth (Procópio et al., 2001). One reason for the overall reduction in cotton seed productivity by combining mixtures in preemergence and application of early postemergence S-metolachlor is perhaps the greatest harm in the cotton plant root system growth, which is essential when this culture is sown in February (second crop conditions).

In the case of herbicides selectivity, productivity determination is crucial, since even with mild visual symptoms of phytotoxicity there may be irreversible impairment of crop yields (Velini et al., 2000). This fact was proven in this experiment, in which treatments that promoted mild symptoms of phytointoxication ended up significantly affecting cotton seeds productivity.

Based on the above, it was found that the application of fomesafen alone or in combination with preemergent prometryn, diuron, trifluralin and S-metolachlor was selective to cotton plant (cultivar DP 555 BGRR $\left.^{\circledR}\right)$. Preemergent fomesafen applied alone followed by early postemergence S-metolachlor application, was also selective to cotton plants (DP 555 BGRR $^{\circledR}$ ). However, the application of tank mixtures involving preemergent fomesafen complemented with the application of early postemergence S-metolachlor was not selective to cotton plant, cultivar DP 555 BGRR $^{\circledR}$.

\section{ACKNOWLEDGMENT}

We thank CNPq [Conselho Nacional de Desenvolvimento Científico e Tecnológico (National Counsel of Technological and Scientific Development)] for granting the scholarship and Fundação Goiás (Goiás Foundation) for the support during the performance of the experiment.

\section{LITERATURE CITED}

ANDRADE JR., E. R. et al. Primeiro relato de Amaranthus palmeri no Brasil em áreas agrícolas no Estado do Mato Grasso. Circular Técnica IMA-MT, n.19, jun. 2015.

Disponível em: <http://www.imamt.com.br/system/anexos/ arquivos/294/original/circular_tecnica_edicao19_bx_ok.pdf? 1434631723>. Acesso em: 21 jun. 2015.
ARANTES, J. G. Z. Seletividade de sistemas de controle químico de plantas daninhas na cultura do algodoeiro. 2012. 165 f. Tese (Doutorado em Agronomia) - Universidade Estadual de Maringá, Maringá-PR, 2012.

ARANTES, J. G. Z. et al. Tolerância de duas variedades de algodoeiro a herbicidas aplicados em pré-emergência. R. Bras. Herb., v. 13, n. 1, p. 31-39, 2014.

ARLE, H. F.; HAMILTON, K. C. Over-the-top applications of herbicides in cotton. Weed Sci., v. 24, n. 2, p. 166-169, 1976.

BELTRÃO, N. E. M. B. Manejo de plantas daninhas em algodão. In: VARGAS, L.; ROMAN, E. S. Manual de manejo e controle de plantas daninhas. Bento Gonçalves: Embrapa Uva e Vinho, 2004. p. 215-250.

BELTRÃO, N. E. M. B. et al. Ecofisiologia do algodoeiro (Gossypium hirsutum L., R. latifolium Hutch). In: BELTRÃO, N. E. M. B.; OLIVEIRA, M. I. P. Ecofisiologia das culturas de algodão, amendoim, gergelim, mamona, pinhãomanso e sisal. Brasília: Embrapa, 2011. p. 65-124.

BELTRÃO, N. E. M. B. et al. Ecofisiologia do algodoeiro. In: BELTRÃO, N. E. M. B.; AZEVEDO, D. M. P. O agronegócio do algodão no Brasil. 2.ed. Brasília: Embrapa, 1999. v. 1. p. 61-109.

BOND, J. A.; OLIVER, L. W.; STEPHENSON IV, D. O. Response of palmer amarath (Amaranthus palmeri) accessions to glyphosate, fomesafen and pyrithiobac. Weed Technol., v. 20, n. 4, p. 885-892, 2006.

CULPEPPER, A. S.; YORK, A. C. Weed management in glyphosate-tolerant cotton. J. Cotton Sci., v. 2, n. 4, p. 174-185, 1998.

DAN, H. A. et al. Seletividade de clomazone isolado ou em mistura para a cultura do algodoeiro. Planta Daninha, v. 29, n. 3, p. 601-607, 2011.

EMPRESA BRASILEIRA DE PESQUISA AGROPECUÁRIA - EMBRAPA. Sistema brasileiro de classificação de solos. 3.ed. Brasília, DF: Embrapa Solos, 2013. 353 p.

EVERMAN, W. J. et al. Weed control and yield with flumioxazin, fomesafen and S-metolachlor systems for glufosinate-resistant cotton residual weed management. Weed Technol., v. 23, n. 3, p. 391-397, 2009.

EUROPEAN WEED RESEARCH COUNCIL - EWRC. Report of $3^{\text {rd }}$ and $4^{\text {th }}$ meetings of EWRC - Committee of Methods in Weed Research. Weed Res., v. 4, n. 1, p. 88, 1964.

Planta Daninha, Viçosa-MG, v. 33, n. 4, p. 759-770, 2015 
FAGLIARI, J. R.; OLIVEIRA JR., R. S.; CONSTANTIN, J. Métodos de avaliação da seletividade de herbicidas para a cultura da cana-de-açúcar (Saccharum spp.). Acta Sci.

Agron., v. 23, n. 4, p. 1229-1234, 2001.

FAUSEY, J. C.; PENNER, D.; RENNER, K. A. Physiological basis for CGA-248757 and flumiclorac selectivity in five plant species. Weed Sci., v. 48, n. 4, p. 405-411, 2000.

GUIMARÃES, S. C.; HRYCYC, M. F.; MENDONÇA, E. A. F. Efeito de fatores ambientais sobre a seletividade de alachlor ao algodoeiro. Planta Daninha, v. 25, n. 4, p. 813-821, 2007.

JACOBS, J. M. et al. Effect of diphenyl ether herbicides on oxidation of protoporphyrinogen to protoporphyrin in organellar and plasma membrane enriched fractions of barley. J. Plant Physiol., v. 97, n. 1, p. 197-203, 1991.

KARPINSKI, R. A. K. et al. Influência da textura do solo na seletividade do herbicida fomesafen aplicado em pré-emergência do algodoeiro. R. Bras. Herb., v. 13, n. 2, p. 125-133, 2014.

MAIN, C. L. et al. Cotton tolerance to fomesafen applied preemergence. J. Cotton Sci., v. 16, n. 1, p. 80-87, 2012.

OOSTERHUIS, D. M. Growth and development of a cotton plant. In: CIA, D.; FREIRE, E. C.; SANTOS, W. J. Cultura do algodoeiro. Campinas: Potafos, 1999. p. 35-55.
PROCÓPIO, S. O. et al. Efeito do tamanho de sementes sobre a tolerância do feijoeiro ao S-metolachlor, em condições de baixa temperatura. R. Bras. Herb., v. 2, n. 3, p. 133-141, 2001.

RAIMONDI, M. A. et al. Períodos de interferência das plantas daninhas na cultura do algodão em semeadura adensada na safrinha. Planta Daninha, v. 32, n. 3, p. 521-532, 2014.

SILVA, C. L. et al. Seletividade de herbicidas aplicados na cultura do algodão adensado. R. Agro@mbiente On-line, v. 7, n. 2, p. 209-2017, 2013.

STEPHENSON IV, D. O. et al. Weed management with fomesafen preemergence in glyphosate-resistant cotton. Weed Technol., v. 18, n. 3, p. 680-686, 2004.

TROXLER, S. C. et al. Clomazone, fomesafen and bromoxynil systems for bromoxynil-resistant cotton (Gossypium hirsutum). Weed Technol., v. 16, n. 4, p. 838-844, 2002.

VELINI, E. D. et al. Avaliação da seletividade da mistura de oxyfluorfen e ametryne, aplicada em pré e pós-emergência, a dez variedades de cana-de-açúcar (cana-planta).

Planta Daninha, v. 18, n. 2, p. 123-134, 2000. 